\title{
ゼロモーメント点の操作による歩行ロボットの制御
}

\author{
水戸部 和 久* 矢 島 克 知* 那須 康 雄*
}

\section{Control of Walking Robots by Manipulating the Zero Moment Point}

\author{
Kazuhisa Mitobe*, Katsutomo Yajima* and Yasuo Nasu*
}

\begin{abstract}
This paper proposes a control method for walking robots by manipulating the zero moment point of the motion. The control law is developed based on a simple model, in which motion of a point mass in a sagital plane is governed by the gravitation and reaction force from the ground. Stability of the system under the control is analyzed by using the state plots of the motion trajectory.

The objective of the control method is to control the balance of the robot without depending on the strict tracking control, which is required, in conventional methods, in order to prevent the robot from falling down.
\end{abstract}

Key Words: Walking Robot, Zero Moment Point, Control, Stability

1. はじめに

産業用ロボットの制御において, 多くの場合, タスクの記述 は手先位置の軌道として記述される。これに対し，歩行ロボッ トの制御においては, どの物理量を制御量として選ぶべきかは 明確に定まっておらず, 歩行の解釈の違いにより異なったもの が考えられる．したがって，タスクの記述方法においても様々 なものが考えられる，例えば，歩容を各関節角度，またはその 軌道としてあらかじめ定め, それを目標軌道として軌道追従制 御を行う方法 [1], ロボットと地面との接地点まわりでの角運動 量を目標の值に制御する方法 [2], ロボットの重心軌道および支 持脚切り換えタイミングを複合的に制御量とする方法 [3], など がある.しかし，どのような制御量を選択する場合でも，以下 の 2 点は歩行ロボットにおいて共通の制御目的と考えられる.

1. ロボットの地面に対する相対位置の移動.

2. バランスの確保（転倒の防止）.

本研究では問題を以上の二つの制御目的に限定して, 歩行口 ボットの制御則に関する議論を行う。

1 番目の制御目的は地面に固定した座標系でのロボットの位 置または軌道の制御の問題と考えることができる。これは通 常の産業用ロボットのタスクの記述と同様である. ただし, 歩 行ロボットはベースリンクが地面に固定されていないために 制御の難しさが生ずる. 2 番目の制御目的はゼロモーメント点 (ZMP) を安定領域の内部に限定する問題として定式化される ことが一般的である [4] [6].これらの二つの制御目的は互いに

原稿受付 1998 年 11 月 19 日

*山形大学工学部

*Faculty of Engineering, Yamagata University
独立ではない。なぜならば，ロボットの地面に対する位置を制 御するためには地面とロボットの間の力の相互作用を能動的 に操作する必要があり, そのためにはロボットがバランスを失 わないことが必要である。 また, 逆にロボットのバランスはロ ボットの運動に影響されるからである.

これらの二つの問題を同時に解決するために，これまでに提 案されている多くの研究では, 安定領域内に ZMP の目標軌道 を設定し，それに基づいてロボットの運動をオフライン的に計 画する方法がとられている。これを人間に当てはめて言い換え ると，上体の運動を規定することにより足から床への反力を制 御することに相当する.

この方法の問題点の一つは, 計画された運動を実現するため の追従制御の性能がロボットのバランスにただちに影響するこ とである，ZMPは関節角度のみでなく角加速度の影響も受け るので, 制御においては加速度レべルまでの軌道追従性が要求 される.実際にはこのような制御は困難であるので計画された ZMP と実際の ZMP との間のずれを補償する方法が種々提案 されている. 例えば, Vukobratovichらは脚を構成する関節の 中の一つに補償入力を加える方法を示している [4]. また, 近 年脚光を浴びている本田技術研究所の人間型ロボットの制御に おいては ZMP の目標值を操作することでロボットの転倒を防 ぐ方法を用いている [5].もう一つの問題点は, ロボットの運動 計画と制御が分離されているために，地面状況の変化などに口 ボットが実時間で適応して歩行することが難しいことである.

本研究では，上述の方法と逆に，ZMPを制御における操作 量として扱うことによりロボットの位置の制御を行う制御則を 検討する。これは, 人間が足から床への反力を操作することに 
より上体のバランスを確保し，あるいは歩行速度を加減速する 状況に相当し，自然な方法と思われる。これにより, 計画軌道 への厳密な追従性を必要とせず, また, 運動の計画と制御を分 離することなしに二つの制御目的を達成することを目的とする。 なお，作業に対して圥長な自由度をもつことは人間の器用さ を与えるうえで重要なことと考えられるが，本研究では午長な 自由度に関する考察を目的とせず，ロボットの地面に対する移 動の制御問題のみを考察することにする。

\section{ZMP の操作に基づく制御則}

\section{1 問題の記述}

Fig. 1 に本研究で考察の対象とするシステムを示す.このシ ステムは平面内を一つの質点が運動するものである。質点の運 動は重力および床から作用する力により支配される。ベクトル $F$ が床から質点に作用する力を表し， $G$ は重力を表す．制御の 目的を床からの力 $F$ を操作することにより平面内における質 点の位置を制御することとする．床からの力 $F$ は実際には脚 の機構を経由して質点に作用するが，本研究では脚機構を特定 せずに質点位置の制御の問題を考察する。

$F$ を延長した線が地面と交わる点が ZMPである，単脚支持 の場合，ZMPがロボットを支持する足底領域内にあればその 足底は床面と密着している. 質点の加速度 $a$ は力 $F$ と重力 $G$ の合力方向に生じ, その運動方程式を水平方向と鉛直方向に分 けて書けば, 次式となる。

$$
\begin{aligned}
& m \ddot{x}=f_{x}, \\
& m \ddot{y}=f_{y}-m g,
\end{aligned}
$$

ここで， $g$ は重力加速度であり， $f_{x}$ および $f_{y}$ は床反力 $F$ の 水平および鉛直成分であり，次式のとおり表される。

$$
\begin{aligned}
f_{x}=|F| \cos (\theta), & f_{y}=|F| \sin (\theta), \\
\cos (\theta) & =\frac{x-x_{z m p}}{\sqrt{\left(x-x_{z m p}\right)^{2}+y^{2}}}, \\
\sin (\theta) & =\frac{y}{\sqrt{\left(x-x_{z m p}\right)^{2}+y^{2}}} .
\end{aligned}
$$

以上の関係式より ZMP を質点の状態 $x, \ddot{x}, y, \ddot{z}$ で表せば次式 となる。

$$
x_{z m p}=\frac{x(\ddot{y}+g)-y \ddot{x}}{\ddot{y}+g} .
$$

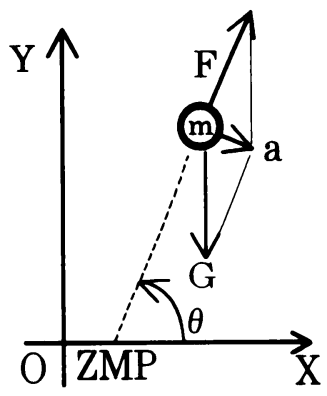

Fig. 1 Motion of a point mass
地面より質点に作用する力 $F$ を任意に操作することが可能で あれば平面内での質点の位置 $(x, y)$ を制御することは容易であ る. 実際のロボットでは $F$ を操作可能か否かは脚の機構など に依存すると考えられる．脚機構に関しては後に具体例を示し 考察することとし，ここでは以下の仮定のもとで制御則を検討 する.

A1. ZMP の座標 $x_{z m p}$ は床面上で任意に操作することがで きる。

A2. ZMP から質点に作用する力の大きさ $|F|$ は任意に操作す ることができる。

実際にはZMP のとりうる範囲は任意ではなく，例えば，単脚 支持期では足底内に限定される。ZMPを限定した制御につい ては 4 章で考察する。

\section{$2.2 \mathrm{ZMP}$ の操作則}

ZMP の目標軌道に基づいてロボットの運動をオフライン的 に計画する方法 [4] を, 問題とするシステムに適用すれば以下 の手順となる。 まず ZMP の軌跡 $x_{z m p}(t)$ の目標を定める.こ れを式 $(6)$ の左辺に代入し時間で積分することにより質点軌 跡 $(x(t), y(t))$ の目標軌道 $\left(x_{d}(t), y_{d}(t)\right)$ を計画する. その際, 式 $(6)$ より $\left(x_{d}(t), y_{d}(t)\right)$ は一意に定まらないので自由度のう ちの一つをあらかじめ定めなければならない，例えば，鉛直方 向への高さ $y$ の目標值は一定值 $y=h_{r e f}$ とし,

$$
x_{z m p}(t)=\frac{x_{d} g-h_{r e f} \ddot{x}_{d}}{g} .
$$

を積分して $x_{d}(t)$ を計画する。このように定めた ZMP および 質点の軌道はノミナル軌道と呼ばれる。制御においては計画さ れた軌道に対して質点位置を追従させる。十分な追従性が得ら れれば ZMPはノミナル軌道に追従すると考えられる。文献 [4] には多自由度を有するロボットに対する軌道計画および制御方 法が示されている. 式 (6) より分かるとおり, 実際の ZMPが ノミナル ZMPに追従するためには $(x, y)$ のノミナルな軌道へ の加速度レベルまでの追従が必要である。ロボットの軌道制御 においては伝達機構における摩擦やバックラッシなどの外乱, 制御におけるモデル化誤差の影響により目標軌道への厳密な追 従は難しい。したがって，実用上はバランス確保のためには， 外乱などに起因する ZMP のノミナルな軌道からのずれの補償 が必要である。文献 [4]では床反力の実測值に基づき補償入力 を生成する一方法が示されている。

上述の方法は，計画された運動を忠実に実行することにより 歩行ロボットのバランスを確保するものである。しかし, 計画 された運動への厳密な追従が要求される点は人間の柔軟な歩行 とは異なるように思われる。そこで本研究では, 計画軌道への 厳密な追従性を要求することなくロボットのバランスの確保お よび移動を行うための制御方法について検討する。

人間は重心の移動やバランスをとるために床に対する反力を 積極的に操作する．例えば重心を後ろに移動させるためにはつ ま先側を地面に対して踏ん張り，逆に重心を前に移動するため にはかかと側を地面に対して踏ん張る。ZMPは床から受ける 力の中心点と考えることができるので，このような重心制御は， ZMP の操作を経由して重心の位置を制御していると解釈でき 


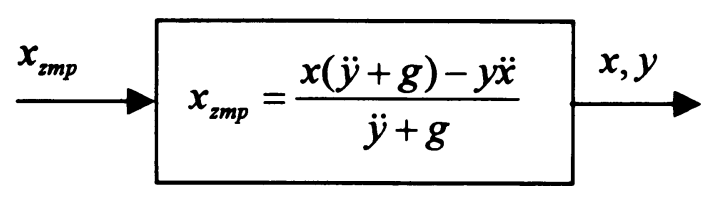

Fig. 2 Manipulation of the ZMP

る。このことを制御系の構成の観点から考えると，重心位置が 被制御量であり，ZMPが操作量であるものと解粕できる。こ のことは，重心軌道を経由して ZMP の軌道を制御する従来方 法において，ZMPが被制御量（あるいはその一部）として扱 われているのと逆の解釈である. 本研究では ZMPを操作量と する立場から，重心を制御するための制御則を検討する。

問題とするシステムでは ZMP の座標は質点の座標 $(x, y)$ を 用いて, 式 (6) で表される。この式を $x_{z m p}$ を入力 $(x, y)$ を出 力とするシステムと考えて Fig. 2 のシステムと見なす.ZMP を操作することにより質点位置 $x$ を制御する，高さ $y$ は ZMP から質点に作用する力の大きさ $F$ を操作することで $x$ と独立 に制御することにする，歩行運動へ応用可能なように，質点を 鉛直方向に一定の高さ $h_{r e f}$ を保ちながら $x$ の正方向一一定速 度で移動させる制御則を考える。まず，質点の高さを制御する ために $F$ の鉛直成分 $f_{y}$ を次式のとおり定める.

$$
f_{y}=h_{\text {ref }}-y-\dot{y}+m g .
$$

これにより $y$ は次の関係を満足するので $h_{r e f}$ に指数関数的に 収束する。

$$
m \ddot{y}+\dot{y}+y=h_{r e f},
$$

次に, 質点の水平方向への座標 $x$ を ZMP の座標の操作によ り制御することを考える。 $x$ の運動は式 (1) を用いて,

$$
\begin{aligned}
m \ddot{x} & =\frac{\cos (\theta)}{\sin (\theta)}\left(h_{r e f}-y-\dot{y}+m g\right), \\
& =\frac{x-x_{z m p}}{y}\left(h_{r e f}-y-\dot{y}+m g\right) .
\end{aligned}
$$

で表される， $\beta$ を以下のとおり定義すれば,

$$
\beta=\frac{m y}{h_{r e f}-y-\dot{y}+m g},
$$

式（10）は単純に次式で表される.

$$
\beta \ddot{x}-x+x_{z m p}=0 .
$$

$y$ が $h_{r e f}$ 一指数関数的に収束するので, $\beta(t)$ は $\frac{h_{r e f}}{g}$ へ指数 関数的に収束する。そこで, $\dot{x}$ を目標值に収束させるために ZMP の座標 $x_{z m p}$ を次式に従い操作する.

$$
x_{z m p}=x+k_{v}\left(\dot{x}-v_{r e f}\right),
$$

ここで, $v_{r e f}$ は質点の水平方向への速度の目標值であり， $k_{v}$ は正の設計ゲインである. $\dot{x}$ の $v_{r e f}$ への収束は正定值関数 $V=\left(\dot{x}-v_{r e f}\right)^{2}$ がリアプノフ関数となっていることから理解 できる、Vを式（12）および式（13）の解に沿って微分すれば,

$$
\dot{V}=-\frac{2 k_{v}}{\beta}\left(\dot{x}-v_{r e f}\right)^{2}=-\frac{2 k_{v}}{\beta} V .
$$

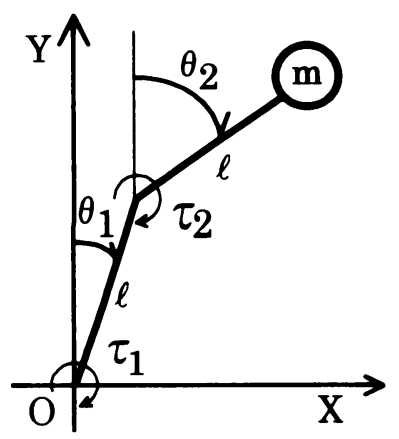

Fig. 3 Example 1

となる.したがって, 正数 $\varepsilon$ が存在して $\frac{1}{\beta} \geq \varepsilon>0$, を満足す れば，

$$
\lim _{t \rightarrow \infty} \dot{x}(t)=v_{r e f} .
$$

すなわち質点は高さを一定に保ちながら水平方向人一定速度で 移動する. $y$ が $h_{r e f}$ に収束しているものとし, $y=h_{r e f}$ に固 定して考えれば，上の条件は $\frac{g}{h_{r e f}} \geq \varepsilon>0$ となる.したがっ て， $\dot{x}$ の収束性は重力が存在しなければ保証されない。このこ とは無重力下で人間の歩行が困難であることと類似であり興味 深い.

歩行の停止状態への応用を考慮し, $x$ を一定値 $x_{r e f}$ 一収束 させるためには式（13）を以下のと抢り変更する.

$$
x_{z m p}=x+\beta\left\{k_{p}\left(x-x_{r e f}\right)+k_{v} \dot{x}\right\} .
$$

ここで， $k_{v}$ および $k_{p}$ は正の設計ゲインである.この場合には， 収束性を保証するためには $\beta \geq \varepsilon_{2}>0$ を満たす正数 $\varepsilon_{2}$ が存 在すれば,

$$
\ddot{x}+k_{v} \dot{x}+k_{p}\left(x-x_{r e f}\right)=0
$$

より $x$ は $x_{r e f}$ に収束する。

\section{3 簡単な脚機構による例}

ここまでの議論は, 脚の機構に関しては具体的に考えていな い. 本節では簡単な脚機構に対して上述の制御則の適用例を示 す。ただし，脚の質量が十分に小さいものと仮定し，支持脚の みを考慮することで議論を簡単化する，また，ロボットの運動 は進行方向平面内に限定されるものとする.式の記述において は $\sin \left(\theta_{i}\right)$ および $\cos \left(\theta_{i}\right)$ を $s_{i}$ および $c_{i}$ により表す。

2.4 例 1

Fig. 3 の脚を考える，脚の質量を無視すれば，質点の運動は 次式を满足する.

$$
\begin{aligned}
& c_{1} \ddot{x}-s_{1} \ddot{y}-g s_{1}=\frac{\tau_{1}}{m l}, \\
& c_{2} \ddot{x}-s_{2} \ddot{y}-g s_{2}=\frac{\tau_{2}}{m l} .
\end{aligned}
$$

ZMP の座標は Fig. 1 の問題と同様に表される.

$$
x_{z m p}=\frac{x(\ddot{y}+g)-y \ddot{x}}{\ddot{y}+g} .
$$

上式は関節へのトルク入力 $\tau_{1}$ および $\tau_{2}$ で表すことができる.

$$
x_{z m p}=\frac{\left(\tau_{1}+\tau_{2}\right)\left(s_{1} c_{2}-c_{1} s_{2}\right) l}{c_{2} \tau_{1}-c_{1} \tau_{2}},
$$


したがって，トルク入力に拘束を与えることにより $x_{z m p}$ を足 底の範囲内で任意に操作することができる．例えば, $x_{z m p}=\delta$ とするためには $\tau_{1}$ および $\tau_{2}$ は次の関係を満足すればよい.

$$
\alpha_{1}\left(\theta_{1}, \theta_{2}, \delta\right) \tau_{1}+\alpha_{2}\left(\theta_{1}, \theta_{2}, \delta\right) \tau_{2}=0
$$
ここで,

$$
\begin{aligned}
& \alpha_{1}=\left(s_{1} c_{2}-c_{1} s_{2}\right) l-\delta c_{2}, \\
& \alpha_{2}=\left(s_{1} c_{2}-c_{1} s_{2}\right) l+\delta c_{1} .
\end{aligned}
$$

新たに入力信号 $u$ を導入することにより $\tau_{1}$ および $\tau_{2}$ を次式 で定める。

$$
\begin{aligned}
& \tau_{1}=\alpha_{2} u, \\
& \tau_{2}=-\alpha_{1} u .
\end{aligned}
$$

$s_{1} c_{2}-c_{1} s_{2} \neq 0$ を仮定し，式（25）および式（26）を式（18） および式（19）に代入すれば次式を得る.

$$
\begin{aligned}
m l \ddot{x} & =\frac{s_{1} \alpha_{1}+s_{2} \alpha_{2}}{c_{1} s_{2}-s_{1} c_{2}} u \\
& =-\left(s_{1}+s_{2}\right) l+\delta u \\
& =-x+\delta u, \\
m l(\ddot{y}+g) & =-\frac{c_{1} \alpha_{1}+c_{2} \alpha_{2}}{c_{1} s_{2}-s_{1} c_{2}} u \\
& =-\left(c_{1}+c_{2}\right) l u \\
& =-y u .
\end{aligned}
$$

したがって，質点の位置は $u$ および ZMPに以下の制御則を適 用すれば制御することが可能である。

$$
\begin{gathered}
u=\frac{1}{y}\left\{k_{p y}\left(y-y_{r e f}\right)+k_{v y} \dot{y}-m l g\right\}, \\
x_{z m p}=\delta=x-\frac{1}{u}\left\{k_{p x}\left(x-x_{r e f}\right)+k_{v x} \dot{x}\right\} .
\end{gathered}
$$

ここで, $\left(x_{r e f}, y_{r e f}\right)$ は $(x, y)$ に対する目標值である. $k_{p}$ およ び $k_{v}$ はフィードバックゲインである。また， $|y|,|u|>0$ を仮 定している.この仮定は式（14）において， $\frac{2}{\beta} \geq \varepsilon>0$ を仮定 したことに相当している.

以上の制御系のブロック図を Fig. 4 に示す。本制御系は質 点の位置制御ループおよび ZMP を指定位置へ拘束するための 制御ループにより構成されている．位置制御ループでは ZMP の指令值 $\delta$ および入力 $u$ に質点座標 $(x, y)$ をフィードバック している，ZMP の制御ループでは，位置制御ループで算出さ れた $\delta に Z \mathrm{ZMP}$ を拘束するようにロボットの関節トルク $\tau_{1}$ お よび $\tau_{2}$ に拘束をあたえている．また，ZMPはロボットの運動 に依存して算出生成されるので常に安定領域, 例えば単脚支持 期における支持脚足底内におさまるとは限らない。ZMPを安 定領域に制限するために図に示すとおり信号 $\delta$ に飽和要素を付 加することが考えられる。この影響については 4 章で検討する.

2.5 例 2

Fig. 5 の脚を考える. 質点の座標 $(x, y)$ の運動を力 $f$ およ びトルク $\tau$ で表せば次式となる.

$$
\begin{aligned}
m l c \ddot{x}-m l s \ddot{y}-m g l s & =\tau, \\
m s \ddot{x}+m c \ddot{y}+m g c & =f .
\end{aligned}
$$

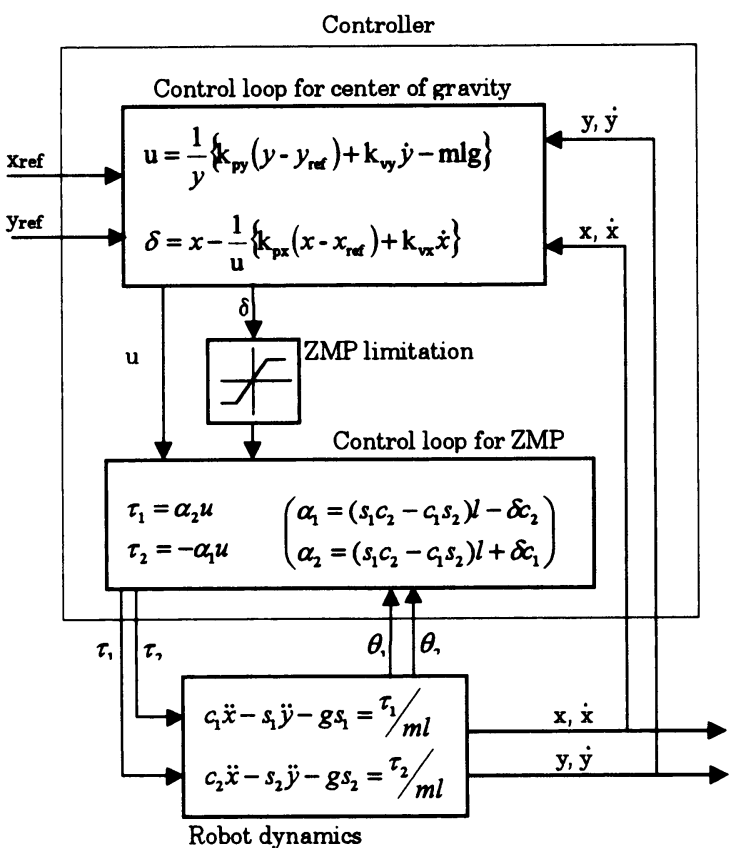

Fig. 4 Block diagram of the controller

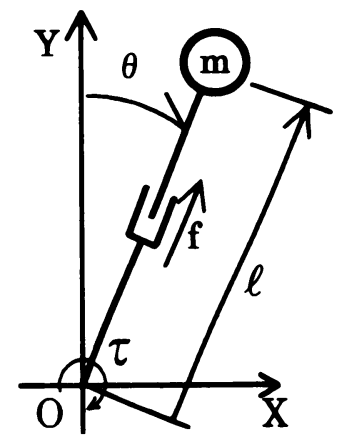

Fig. 5 Example 2

ここで， $s$ および $c$ は $\sin (\theta)$ および $\cos (\theta)$ をそれぞれ表す. $x_{z m p}=\delta$ に指定するために $\tau$ および $f$ に次式の拘束を与える.

$$
\delta c l f+(l-\delta s) \tau=0 .
$$

そのために $\tau$ および $f$ を以下のとおり定める.

$$
\begin{aligned}
& f=(l-\delta s) u, \\
& \tau=-\delta c l u
\end{aligned}
$$

これにより質点の運動は次式に従う。

$$
\begin{aligned}
& m \ddot{x}=(x-\delta) u, \\
& m \ddot{y}=y u-m g .
\end{aligned}
$$

質点位置を制御するために，uおよび ZMP を次式で定める.

$$
\begin{aligned}
u & =\frac{1}{y}\left\{-k_{p y}\left(y-y_{r e f}\right)-k_{v y} \dot{y}+m g\right\}, \\
x_{z m p} & =\delta=x+\frac{1}{u}\left\{k_{p x}\left(x-x_{r e f}\right)+k_{v x} \dot{x}\right\} .
\end{aligned}
$$




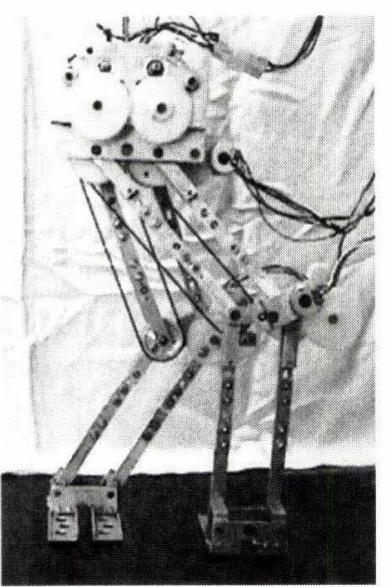

Fig. 6 Experimental leg mechanism
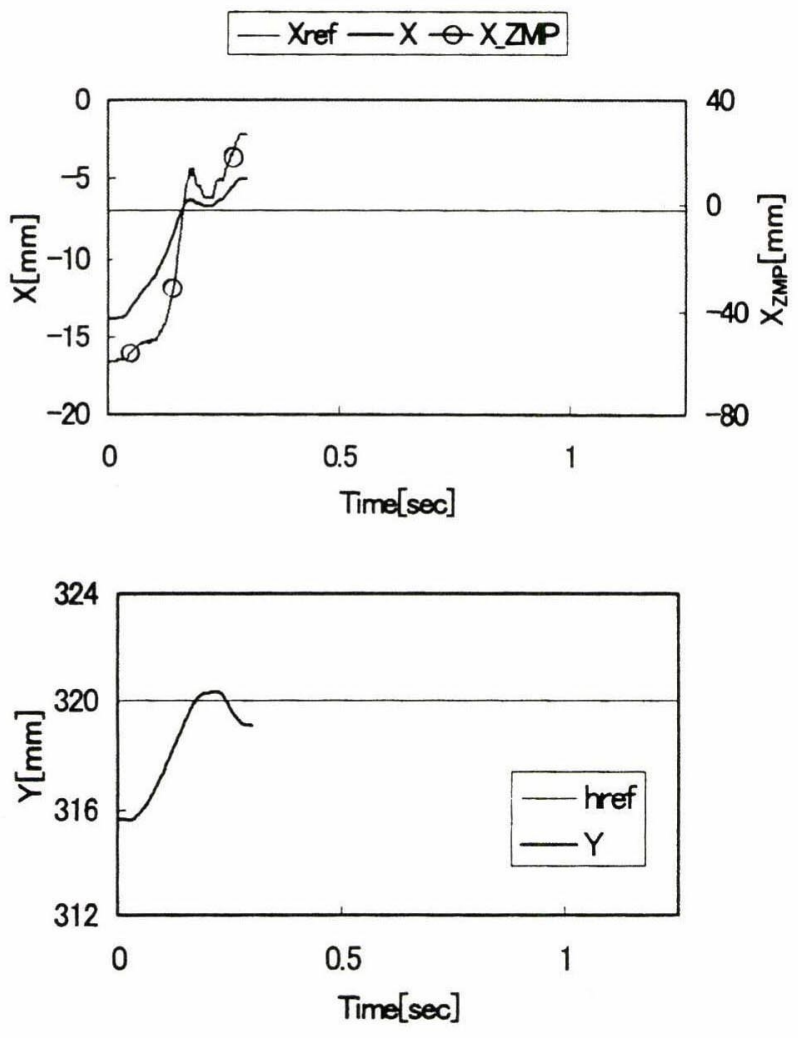

Fig. 7 Step response of the trunk position

\section{3. 実験による検討}

上述の制御則の歩行運動制御への適用可能性を検討するため に, Fig. 6 に示す脚ロボットを用いてロボットの重心位置を 制御する実験を行った。本ロボットの脚は平行リンクを組み合 わせた構成であり, 足底が床面に密着している限り胴体の姿勢 が床面に対して一定に保たれる。ロボットの運動は平面内に限 定されており，モータおよび減速機構が胴体部分に集中されて いるので脚の質量は胴体部分に比べ十分に小さいものと見な す。また，胴体位置の移動を質点移動と見なし，Fig. 3 と同様
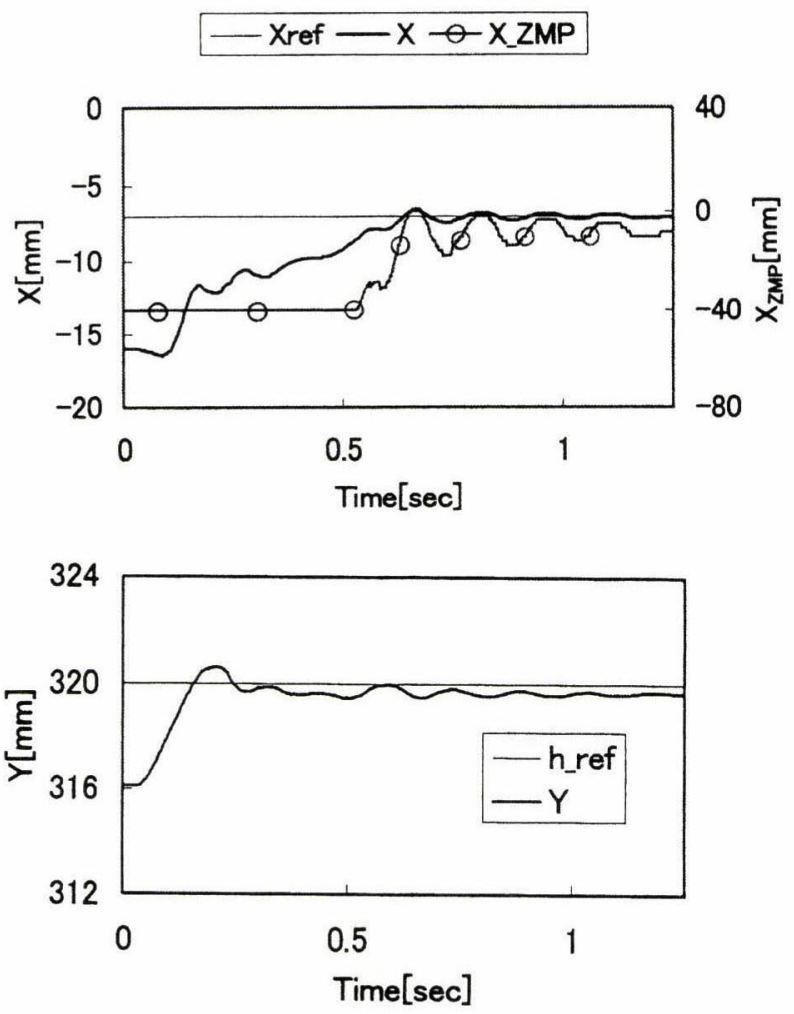

Fig. 8 Step response under ZMP limitation

にモデル化する。リンク長さ $l=138[\mathrm{~mm}]$ であり, 総重量は $1.54[\mathrm{~kg}]$, 一脚あたりの重量は $0.32[\mathrm{~kg}]$ である. 本ロボットの 詳細に関しては文献 $[7]$ に記されている。ロボットが一方の脚の みで重心を支持している状態で, 胴体位置の床からの高さの目 標値を $320[\mathrm{~mm}]$ とし,$x$ を正方向へ $8[\mathrm{~mm}]$ 移動したステップ 応答を Fig. 7 に示す.グラフにおいて座標の原点はロボット足 底部分の中央であり, $\pm 27[\mathrm{~mm}]$ の範囲が足底の範囲に相当し ている。また，グラフ中に示したZMPの位置は制御則式 (30) により与えられるZMP の指令值 $\delta$ の值を表す。本実験では胴 体位置が目標位置に到達した後に行き過ぎを生じ，ロボットの 足底が床から浮き上がり転倒してしまった。理論上は ZMP が 足底内に限定されるならば足底の床からの浮き上がりは生じな いものと考えれるので, 制御則の ZMP の操作に Fig. 4 に示す とおり飽和要素を付加して限定を与え同じ実験を行った。この 結果を Fig. 8 に示す，ZMPの限定により胴体位置の急激な立 ち上がりが抑制されていることが分かる。また，胴体位置が最 終的に目標位置へ収束し，ロボットが転倒することなく追従制 御が有効に働いていることが分かる。なお，本実験においては ZMP の範囲の幅は $80[\mathrm{~mm}]$ としている。この值は, 減速機お よび伝達機構に存在する摩擦の影響を考慮し, 実際の足底幅よ りも大きく設定している.

\section{ZMP を限定した制御則}

2 章の議論において, 質点の軌道追従に関する解析は ZMP の操作範囲を限定せずに行った。ここでは, 再び Fig. 1 のモデ ルを用いて，ZMP の操作範囲に Fig. 4 に示すとおり制限を与. 
えて同様の制御を行った場合の解析を行う. 質点の鉛直方向座 標 $y$ は $x$ と独立に制御し， $h_{r e f}$ に収束させることが可能と考 えて, 以下の議論は $y$ を一定値 $h_{r e f}$ に固定して簡単化する. 制御則式（16）において ZMP を操作する範囲に飽和を与え, 次式のとおり変更する.

$x_{z m p}= \begin{cases}\underline{x}_{z m p} & x+\beta^{*}\left\{k_{v} \dot{x}+k_{p}\left(x-x_{r e f}\right)\right\}<\underline{x}_{z m p} \\ \bar{x}_{z m p} \quad \bar{x}_{z m p}<x+\beta^{*}\left\{k_{v} \dot{x}+k_{p}\left(x-x_{r e f}\right)\right\} \\ x+\beta^{*}\left\{k_{v} \dot{x}+k_{p}\left(x-x_{r e f}\right)\right\} \quad \text { otherwise, }\end{cases}$

ここで, $\beta^{*}=h_{r e f} / g$ である. $\underline{x}_{z m p}$ および $\bar{x}_{z m p}$ は ZMP の 上限および下限である。具体的なロボットにおいては，例えば 単脚支持期においては Fig. 9 のように支持している足底の範 囲に収まるようにこれらの值を決定する， $x$ が静止していると きZMPは質点の真下なので, $x$ に対する目標値 $x_{r e f}$ は $\underline{x}_{z m p}$ および $\bar{x}_{z m p}$ の間の值とする. 制御のもとでの質点の運動は位 相平面上に軌道をプロットすれば理解が容易である．Fig. 10 は位相平面上での軌跡の例である．直線 $l_{1}$ および $l_{2}$ は飽和に かかる領域との境界を示しており， $x$ 軸との交点座標 $x_{1}$ およ び $x_{2}$ を $\underline{x}_{z m p}$ および $\bar{x}_{z m p}$ と比較すれば次式を満足する.

$$
\begin{aligned}
& x_{1}-\underline{x}_{z m p}=\frac{\beta^{*} k_{p}}{1+\beta^{*} k_{p}}\left(x_{r e f}-\underline{x}_{z m p}\right)>0, \\
& x_{2}-\bar{x}_{z m p}=\frac{\beta^{*} k_{p}}{1+\beta^{*} k_{p}}\left(x_{r e f}-\bar{x}_{z m p}\right)<0 .
\end{aligned}
$$

したがって, 次の関係がある。

$$
\underline{x}_{z m p}<x_{1}<x_{r e f}<x_{2}<\bar{x}_{z m p} .
$$

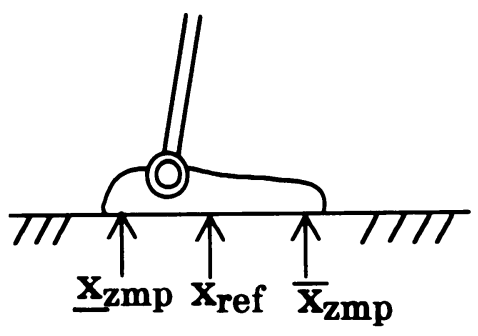

Fig. $9 \underline{x}_{z m p}$ and $\bar{x}_{z m p}$

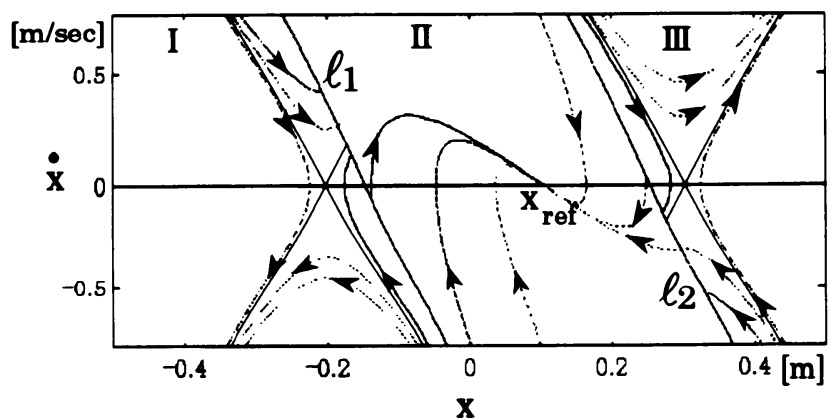

Fig. 10 Phase plane for $k_{v}=1.7, k_{p}=2.9, h_{\text {ref }}=0.3, \underline{x}_{z m p}=$ $-0.2, \bar{x}_{z m p}=0.3$
各領域内での $x$ の運動は式 $(12)$ および式 $(40)$ より，以下の とおり表される。領域 I および III においては ZMP は固定点 となるので, 質点の運動は文献 [3]に示されている線形倒立振 子モードと等しくなる.

• 領域 I

$$
\beta^{*} \ddot{x}-x+\underline{x}_{z m p}=0
$$

• 領域 II

$$
\ddot{x}+k_{v} \dot{x}+k_{p}\left(x-x_{r e f}\right)=0
$$

• 領域 III

$$
\beta^{*} \ddot{x}-x+\bar{x}_{z m p}=0
$$

目標位置 $x=x_{r e f}$ の安定性は領域を区別する直線 $l_{1}$ および $l_{2}$ の傾き $-\frac{1+\beta^{*} k_{p}}{\beta^{*} k_{v}}$ と領域 I および IIIにおける運動を表すシ ステム行列

$$
\left[\begin{array}{cc}
0 & 1 \\
-1 / \beta^{*} & 0
\end{array}\right]
$$

の固有ベクトルの傾き, $-\frac{1}{\sqrt{\beta^{*}}}$ を比較することで判別すること ができる. Fig. 10 は直線の傾きが $-\frac{1}{\sqrt{\beta^{*}}}$ 以上, すなわち,

$$
-\frac{1+\beta^{*} k_{p}}{\beta^{*} k_{v}} \geq-\frac{1}{\sqrt{\beta^{*}}}
$$

の場合の軌跡の例を示す. 図より分かるとおり, 領域 II より出 発した，どの軌跡も目標值 $\left(x_{r e f}, 0\right)$ 一収束する. 条件式 $(48)$ 式を $\sqrt{\beta^{*}}$ に関して整理すれば次式の条件となる.

$\frac{k_{v}-\sqrt{k_{v}^{2}-4 k_{p}}}{2 k_{p}} \leq \sqrt{\beta^{*}}\left(=\sqrt{\frac{h_{r e f}}{g}}\right) \leq \frac{k_{v}+\sqrt{k_{v}^{2}-4 k_{p}}}{2 k_{p}}$.

これより，質点の高さ $h_{\text {ref }}$ が十分に高くなればこの条件は満 足されなくなり，発散する軌道が生じることが分かる. Fig. 11 は直線の傾きが $-\frac{1}{\sqrt{\beta^{*}}}$ より小さい場合，すなわち，

$$
-\frac{1+\beta^{*} k_{p}}{\beta^{*} k_{v}}<-\frac{1}{\sqrt{\beta^{*}}},
$$

のときの軌跡の例である。このときには初期值に依存して，解 軌道は $\left(x_{r e f}, 0\right)$ 一収束する場合と発散する場合がある。実際 の歩行においては運動軌道が発散する場合には転倒を防ぐため 支持脚の切り換えが必要である。条件式（50）より位置制御の フィードバックゲイン $k_{p}$ が大きくなると発散する運動軌道が 生じることが分かる.

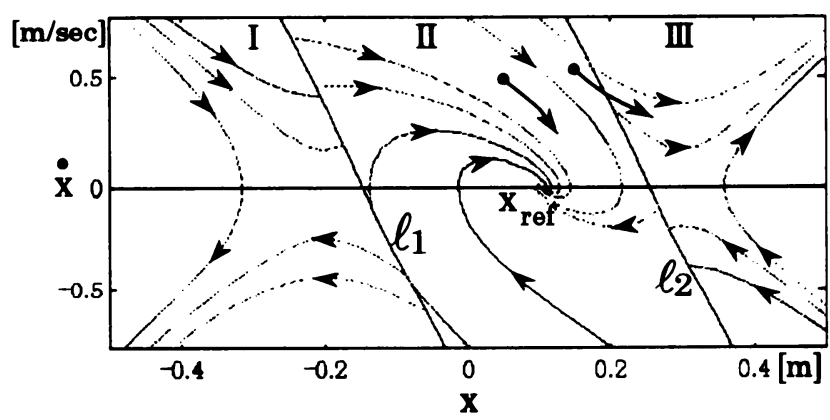

Fig. 11 Phase plane for $k_{v}=0.9, k_{y}=0.6, h_{\text {ref }}=1.0, \underline{x}_{z m p}=$ $-0.2, \bar{x}_{z m p}=0.3$ 


\section{5. おわりに}

本論文は歩行ロボットの ZMP の操作に基つくく制御則を提案 し, 安定性に関する検討を行った。その目的は, 計画された運 動への㛜密な追従を必要とせずに，ロボットの移動とバランス の確保を同時に行うことである。得られた結果は，平面内を質 点が移動する単純なモデルに基づいているが，ロボット胴体部 の姿勢変化が少なく近似的に質点移動と見なせる歩行運動へ応 用可能と考えられる。人間に近い多自由度のロボットに対して は制御則の一般化が必要であり, 今後の課題である。

\section{参 考 文 献}

[1] F. Miyazaki and S. Arimoto: "A Control Theoretic Study on Dynamical Biped Locomotion," Transactions of the ASME, Journal of Dynamic Systems, Measurement, and Control, vol.102, pp.233-239, 1980

[2] 佐野, 古荘：“角運動量制御による 2 足歩行ロボットの 3 次元動歩 行”, 計測自動制御学会論文集, vol.26, no.4, pp.459-466, 1990.

[3] 梶田, 小林：“位置エネルギー保存軌道を規範とする動的 2 足歩行の 制御”, 計測自動制御学会論文集, vol.23, no.3, pp.281-287, 1987.

[4] M. Vukobratovich, B. Borovac, D. Surla and D. Stokic: Biped Locomotion, Dynamics, Stability, Control and Application. Springer Verlag, 1990.

[5] K. Hirai, M. Hirose, Y. Haikawa and T. Takenaka: "The Development of Honda Humanoid Robot," Proceedings of the 1998 IEEE International Conference on Robotics \& Automation, pp.1321-1326, 1998.

[6] 高西, 石田, 山崎, 加藤：“2 足歩行ロボットWL-10RDによる動歩 行の実現”, 日本ロボット学会誌, vol.3, no.4, pp.67-78, 1985.

[7] 水戸部, 森, 相田, 那須：“非線形フィードバックによる二足歩行ロ ボットの制御”, 日本ロボット学会誌, vol.14, no.8, pp.1194-1199, 1996.

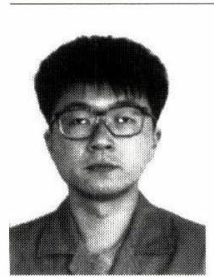

水戸部和久 (Kazuhisa Mitobe)

1963 年 6 月 18 日生. 1988 年新潟大学大学院工学 研究科修士課程精密工学専攻修了. 1990 年新潟大 学大学院自然科学研究科博士課程生産科学専攻中 退, 山形大学工学部機械システム工学科助手, 1998 年同助教授，現在に至る。博士（工学）。計測自動 制御学会, システム制御情報学会, 日本機械学会, 精密工学会, IEEEの会員.

(日本ロボット学会正会員)

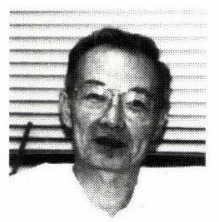

那須康雄 (Yasuo Nasu)

1939 年 3 月 7 日生. 1964 年大阪大学大学院工学 研究科修士課程修了. 同年山形大学工学部精密工 学科助手. 1965 年同講師, 1977 年同助教授, 1984 年同教授. 現在, 同機械システム工学科教授. 工学 博士、ロボットを用いた各種手作業代替システム, 2 足歩行機械, 人工関節コンポーネントの高性能化 に関する研究などに従事. 日本機械学会, 精密工学会, 溶接学会, 日 本材料学会などの会員.
(日本ロボット学会正会員)

\section{矢島克知 (Katsutomo Yajima)}

1974 年 5 月 17 日生. 1999 年山形大学大学院工学 研究科博士前期課程機械システム工学専攻修了, 現 在（株）トキメック勤務.

(日本ロボット学会学生会員) 